DOI: $10.25140 / 2411-5215-2019-4(20)-342-352$

Свгенія Полішук, Вікторія Орел

\title{
ГЛОБАЛЬНІ ТЕНДЕНЦІЇ РОЗВИТКУ КРЕДИТНИХ СПІЛОК
}

\author{
Евгения Полищук, Виктория Орел
}

ГЛОБАЛЬНЫЕ ТЕНДЕНЦИИ РАЗВИТИЯ КРЕДИТНЫХ СОЮЗОВ

\section{Yevheniia Polishchuk, Viktoriia Orel \\ GLOBAL TENDENCIES OF CREDIT UNIONS' DEVELOPMENT}

У статті опубліковано результати дослідження, які були спрямовані на виявлення глобальних тендениій розвитку кредитних спілок. Також було надано рекомендації щуодо менеджменту діяльності кредитних спілок України в розрізі виявлених тендениій. Було виявлено крос-регіональні особливості кредитних спілок у глобальному вимірі. Виявлено ті FinTech інструменти, які сприяють розвитку цих фінансових посередників. Проаналізовано діяльність кредитних спілок в Україні та з'ясовано специфіку їх розвитку. У статті доведено, ияо найближчим часом ринок кредитних спілок і надалі зростатиме й нині немає передумов для його стрімкого падіння, водночас менеджмент кредитних спілок повинен врахувати ймовірність настання нової фінансової кризи. Стаття буде иікава менеджерам кредитних спілок, регуляторам фінансового ринку, а також науковиям з відповідним науковим інтересом.

Ключові слова: кредитна спілка; кредит; активи; показник проникнення; член кредитної спілки; кооператив.

Рис.: 2. Табл.: 1. Бібл.: 29.

В статье опубликованы результаты исследования, направленные на выявление глобальных тенденций развития кредитных союзов. Также были предоставлены рекомендации относительно менеджмента деятельности кредитных союзов Украины в разрезе выявленных тендениий. Были обнаружены кросс-региональные особенности кредитных союзов в глобальном измерении. Выявлено те FinTесh инструменты, которые способствуют развитию этих финансовых посредников. Проанализирована деятельность кредитных союзов в Украине и выяснена специфика их развития. В статье доказано, что в ближайшее время рынок кредитных союзов и в дальнейшем будет расти и на сегодняшний день нет предпосылок для его стремительного падения, в то же время менеджмент кредитных союзов должен учесть вероятность наступления нового финансового кризиса. Статья будет интересна менеджерам кредитных союзов, регуляторам финансового рынка, а также ученым с соответствуюшим научным интересом.

Ключевые слова: кредитный союз; кредит; активы; показатель проникновения; член кредитного союза; кооператив.

Рис.: 2. Табл.: 1. Библ.: 29

The article presents the results of a study aimed at identifying global trends in the development of credit unions. Recommendations were also given on the management of credit unions in Ukraine in the light of trends identified. Crossregional features of credit unions in the global dimension have been identified. Those FinTech tools that promote the development of these financial intermediaries have been identified. The activity of credit unions in Ukraine is analyzed and the specifics of their development are determined. In the article it is proved that in the near future the market of credit unions will continue to grow and today there are no prerequisites for its rapid decline, at the same time, the management of credit unions must take into account the likelihood of a new financial crisis. The article will be of interest to credit union managers, financial market regulators, and academics with relevant scientific interest.

Keywords: Credit Union; credit; assets; penetration rate; member of the credit union; cooperative.

Fig.: 2. Table: 1. References: 29.

JEL Classification: G23; G53

Постановка проблеми. Кредитні спілки $\epsilon$ важливою складовою фінансової інфраструктури будь-якої країни. Останніми роками ринок послуг кредитних спілок стрімко зростає, що пояснюється зростанням попиту населення і підвищенням рівня довіри до небанківських фінансових інституцій. Ця тенденція зумовлює необхідність дослідження стану ринку на сьогодні та прогнозування його майбутніх показників.

За своєю правовою природою кредитні спілки є специфічними організаціями фінансової взаємодопомоги громадян, що мають неприбуткову кооперативну основу й по суті своєї діяльності схожі на інших учасників ринку - банки. Їхня головна мета - фінансовий та соціальний захист своїх членів шляхом залучення їхніх особистих заощаджень для взаємного кредитування, фінансової підтримки підприємницьких ініціатив та надання їм інших фінансових послуг.

Підвищення рівня конкурентоспроможності кредитної спілки на ринку фінансових послуг також можливо за рахунок розширення асортименту наданих послуг, а також використання різних FinTech можливостей. Нині кредитні спілки в розвинутих країнах

(C) Поліщук С. А., Орел В. С., 2019 
ФІНАНСОВІ РЕСУРСИ: ПРОБЛЕМИ ФОРМУВАННЯ ТА ВИКОРИСТАННЯ

активно використовують цю можливість. Вітчизняні кредитні спілки також намагаються застосовувати найсучасніші технології. Водночас вони повинні враховувати не тільки вітчизняні реалії ринку, але і глобальні тенденції розвитку.

Аналіз останніх досліджень і публікацій. Проблеми діяльності кредитних спілок $\epsilon$ об’єктом наукового інтересу багатьох вітчизняних та закордонних дослідників. На сьогодні сучасні науковці застосовують декілька підходів, які лягли в основу досліджень кредитних спілок.

У багатьох працях досліджено розвиток кредитних спілок у світі. Зокрема, Є. С. Осадчий розглядає діяльність кредитних спілок у світі за період 1995-2015 роки, що дає змогу ширше оцінити тенденції розвитку кредитних спілок на майбутні роки [6]. Р. Руська вивчала діяльність кредитних спілок у світі шляхом побудови економікоматематичних моделей. Авторка обгрунтувала кореляцію показників діяльності кредитних спілок і зробила висновки щодо особливостей діяльності спілок у різних регіонах [8].

Нещодавні праці закордонних науковців, фахівців та практиків (R. Morgan [23], J. Chambers [20], R. McDermott [26]) здебільшого стосуються впливу Fintech на розвиток індустрії кредитних спілок. В їхніх статтях виокремлено декілька порад, за допомогою яких кредитні спілки можуть розвиватися на ринку в часи цифровізації економіки (Gold [16], Hemon-Laurens [17]). Зокрема, до них належать використання сучасними кредитними спілками таких інструментів: діджитал кредитування (тут і зараз), використання біометрики, клієнтських даних Big Data, регуляторних технологій, штучного інтелекту, інтернету речей, «хмарних» рішень та мобільних додатків. Експерти радять звернути увагу на розвиток інноваційних фінансових технологій і застосовувати нові можливості для розширення своєї діяльності (R. McDermott [26]). Найбільш влучною рекомендацією фахівців також є те, що кредитні спілки мають не зливатися з ринком, а відокремлюватись від нього. Тобто вони мають виділятися своїми послугами, що відрізнятимуться від інших суб'єктів ринку фінансових послуг [27; 24]. Поряд із впровадженням інновацій їм також варто використовувати й сильні історичні сторони для управління «моментами правди» клієнта (тобто використовувати те, що вже випробувано роками, і те, до чого звикли клієнти) (Т. Boles [19]). Для оптимізації роботи кредитної спілки варто створювати невеликі та цілеспрямовані команди, оскільки організації можуть керувати успішними проєктами цифрової трансформації з невеликими командами, захищеними від решти організації та наділеними єдиною метою внесення змін.

Нині в інформаційному просторі також є чимала кількість праць, яка стосується передбачення трендів розвитку кредитних спілок у світі. Зокрема, у працях В. Streeter [28], B. Handel [22], T. O'Hara [25], L. Wingard [29], T. Boles [19], T. Belekevich [18] зазначено, що в найближчому майбутньому кредитні спілки будуть наслідувати тенденції цифровізації усього фінансового ринку, а саме: Чат-боти 24/7, зменшення кількості традиційних відділень та їх осучаснення, перехід до дистанційного обслуговування клієнтів, безпосередня взаємодія з клієнтами.

Що стосується кредитних спілок в Україні, то особливості їхньої діяльності були досліджені Н. В. Савчук [9], О. М. Осадець та Н. Р. Швець [5]. Автори досить повно здійснили аналіз діяльності кредитних спілок в Україні та визначили проблеми їхнього розвитку.

Виділення недосліджених частин загальної проблеми. Попри доволі потужний пласт наукових досліджень у цій галузі, на жаль, вони не повною мірою відображають необхідні науково обгрунтовані заходи, які б сприяли розвитку кредитних спілок у сучасній українській економіці. Натомість у цій статті запропоновано авторське бачення імплементації закордонного досвіду їхньої діяльності в контексті розвитку сучасних інформаційних технологій. 
ФІНАНСОВІ РЕСУРСИ: ПРОБЛЕМИ ФОРМУВАННЯ ТА ВИКОРИСТАННЯ

Мета статті. У зв'язку з вищезазначеним метою дослідження $є$ визначення тенденцій розвитку кредитних спілок у світі, а також надання рекомендацій щодо їх функціонування в Україні. Для досягнення мети дослідження було виконано такі завдання: проаналізовано показники діяльності кредитних спілок у світі та Україні на основі даних Всесвітньої ради кредитних спілок (World Council of Credit Unions, далі - WOCCU) та визначено особливості їх розвитку для пояснення причинно-наслідкових зв’язків; розкрито крос-регіональні особливості розвитку кредитних спілок; охарактеризовано сучасні FinTech інструменти, які сприяють розвитку кредитних спілок у світі; надано практичні рекомендації щодо їх використання в Україні.

Було ретельно досліджено масштабність діяльності кредитних спілок у світі за допомогою методів дескриптивної статистики, проведено аналіз статистичних даних WOCCU, Національної комісії, що здійснює державне регулювання у сфері ринків фінансових послуг (далі Нацкомфінпослуг), Національної асоціації Федеральних кредитних спілок, звіту «Fintech Credit Union Management», які допомогли досягти поставленої мети дослідження. На основі цих даних було здійснено ретроспективний аналіз кредитних спілок, досліджено масштабність їхньої діяльності як загалом, так і окремо по регіонах. У процесі дослідження також було використано пошуковий, описовий та причинно-наслідковий аналіз діяльності кредитних спілок в Україні та світі. Часовий горизонт дослідження: 2013-2018 pр.

Виклад основного матеріалу. Проведення аналізу масштабів діяльності кредитних спілок у світі дає змогу дослідити значення кредитних спілок, визначити темпи розвитку їхньої діяльності, виявити тенденції їхнього подальшого розвитку та надати рекомендації щодо використання новітніх технологій на ринку кредитних спілок.

\section{Теоретичні засади функціонування кредитних спілок в Україні}

Кредитна спілка - це один із видів фінансових кооперативів, що надають здебільшого традиційні банківські послуги. За розмірами кредитні спілки можуть бути як великими, так і малими, що створені, наприклад, певним підприємством для співробітників. Кредитні спілки створюються їхніми учасниками, які і здійснюють їх управління [6].

Як і банки, кредитні спілки, діючи в статусі фінансових посередників, акумулюють кошти від тих, хто в цей момент відчуває їх надлишок, і передають тим, хто відчуває в них нагальну потребу.

Але головною відмінністю між цими структурами є мета їхньої діяльності: отримання прибутку для банку й надання фінансових послуг для кредитної спілки, а також те, що остання обслуговує тільки своїх учасників.

Певні переваги кредитних спілок перед банками зумовили динаміку їх поширення, яка полягає в тому, що банкам не завжди вигідно мати справу з дрібними позичальниками через значні адміністративні витрати, а кредитні спілки максимально наближені до безпосередніх отримувачів послуг та мають можливість надати кредит за спрощеною процедурою.

Кредитні спілки на глобальному рівні регулюються засадами Всесвітньої ради кредитних спілок. Вона сприяє самодостатньому розвитку кредитних спілок та інших фінансових кооперативів по всьому світу, щоб розширити можливості населення шляхом забезпечення доступу до фінансових послуг високої якості. Всесвітня рада виступає від імені глобальної системи кредитних спілок перед міжнародними організаціями та працює 3 національними урядами 3 метою вдосконалення законодавства та регулювання. Серед iї програм технічної допомоги впровадження нових інструментів, спрямованих на підвищення рівня фінансової стабільності кредитних спілок. В Україні діяльність кредитних спілок регулюється спеціальним Законом «Про кредитні спілки» [7]. 
ФІНАНСОВІ РЕСУРСИ: ПРОБЛЕМИ ФОРМУВАННЯ ТА ВИКОРИСТАННЯ

\section{Діяльність кредитних спілок у світі}

Останніми роками спостерігається значне розширення діяльності кредитних спілок. За даними Всесвітньої ради кредитних спілок на 2018 рік у світі функціонує більше ніж 85 тис. кредитних спілок (рис. 1), які проводять свою діяльність у 118 країнах.

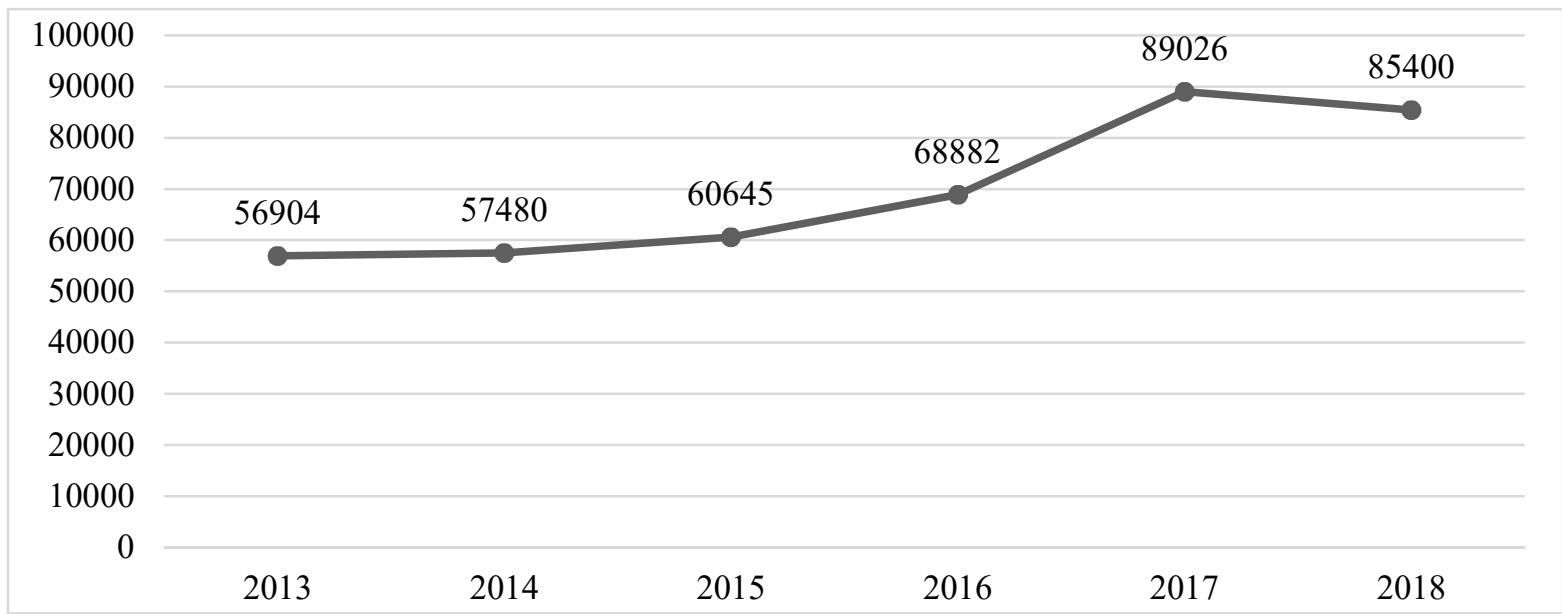

Рис. 1. Динаміка кількості кредитних спілок у світі в період з 2013 по 2018 рр., одиниць

Джерело: [10-15].

32013 року можна спостерігати стрімке зростання кількості кредитних спілок у світі й, попри незначне падіння у 2018 році, їх кількість за 5 років зросла на $50 \%$, або на 28498 організацій. Як видно з рис. 1, найбільше зростання припало на 2017 рік. Кількість кредитних спілок зросла на 20144 організації, із них 15883 - це кредитні спілки країн Африки.

Для визначення тенденції діяльності кредитних спілок на наступний рік було використано дані статистичних звітів WOCCU, витяг за якими надано в таблиці.

Таблиця

Показники діяльності кредитних спілок у світі за 2013-2018 рр.

\begin{tabular}{|c|c|c|c|c|c|c|c|}
\hline Рік & $\begin{array}{c}\text { Кількість } \\
\text { кредитних } \\
\text { спілок, шт. }\end{array}$ & Члени, осіб & $\begin{array}{c}\text { Показник } \\
\text { проникнення }\end{array}$ & $\begin{array}{c}\text { Ощадні рахунки, } \\
\text { дол. США }\end{array}$ & $\begin{array}{c}\text { Кредити, } \\
\text { дол. США }\end{array}$ & $\begin{array}{c}\text { Резерви, } \\
\text { дол. США }\end{array}$ & $\begin{array}{c}\text { Активи, } \\
\text { дол. США }\end{array}$ \\
\hline 2013 & 56904 & 207935920 & $8,06 \%$ & 1433306753707 & 1135173182580 & 171626687472 & 1732945830628 \\
\hline 2014 & 57480 & 217373324 & $8,20 \%$ & 1470863017620 & 1203039908250 & 181447651071 & 1792935093481 \\
\hline 2015 & 60645 & 222798027 & $8,30 \%$ & 1507944065420 & 1242397017615 & 185287266533 & 1844668066851 \\
\hline 2016 & 68882 & 235762076 & $13,55 \%$ & 1465792098297 & 1217337994047 & 170195493093 & 1764682450003 \\
\hline 2017 & 89026 & 260164742 & $9,09 \%$ & 1736954467240 & 1504117294474 & 195578334040 & 2115016371443 \\
\hline 2018 & 85400 & 274227022 & $9,38 \%$ & 1802240534269 & 1610124817694 & 205527280433 & 2191086346008 \\
\hline
\end{tabular}

Джерело: побудовано за даними WOCCU [10-15].

За даними таблиці чітко прослідковується зростання всіх показників, крім кількості кредитних спілок. Найбільшим скороченням (на 4242 організації) позначився азійський регіон. Водночас усі інші показники мають тенденцію до зростання. Тому причиною скорочення кількості кредитних спілок в Азії, так само як і в країнах Північної Америки, $є$ не що інше, як конкуренція. Більші кредитні спілки мають більший обсяг активів, за допомогою якого мають значно ширші можливості для розвитку своєї діяльності.

\section{Крос-регіональні особливості розвитку кредитних спілок}

Для того щоб оцінити динаміку зміни масштабності діяльності кредитних спілок за регіонами, варто розглянути такі діаграми (рис. 2, a-e): 

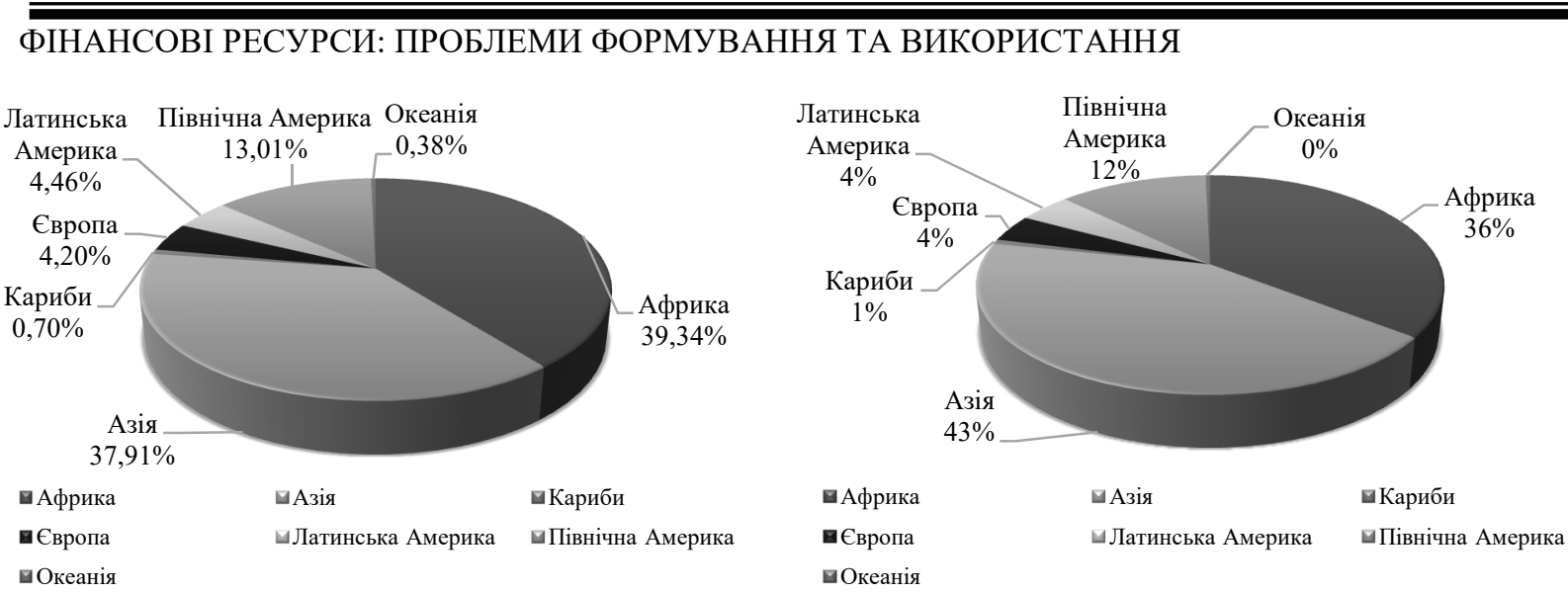

$a$

Європа Латинська Північна

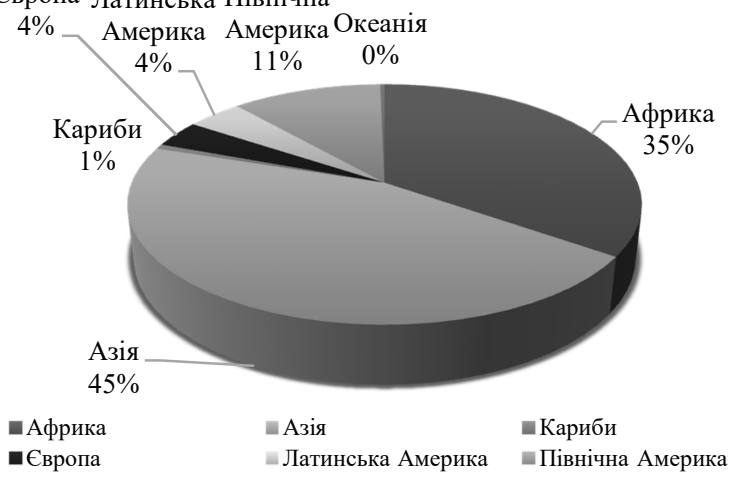

Європа

- Латинська Америка північна Америка

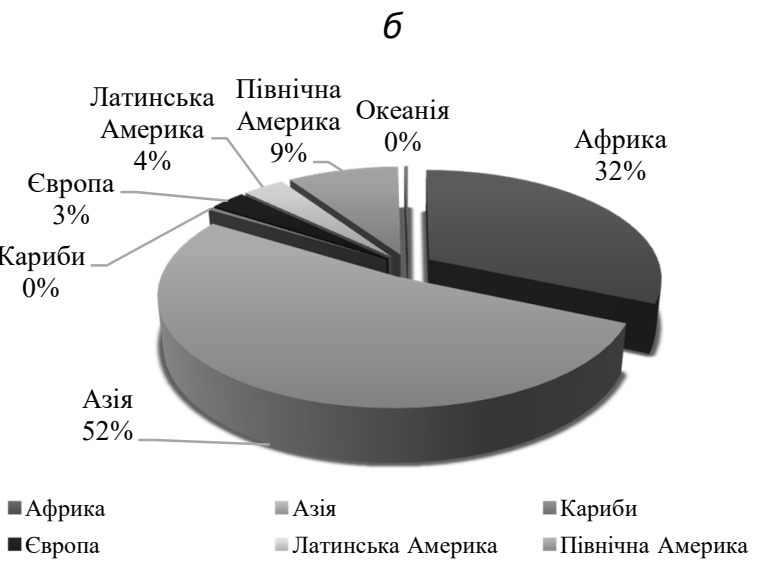

8

шокеанія

2

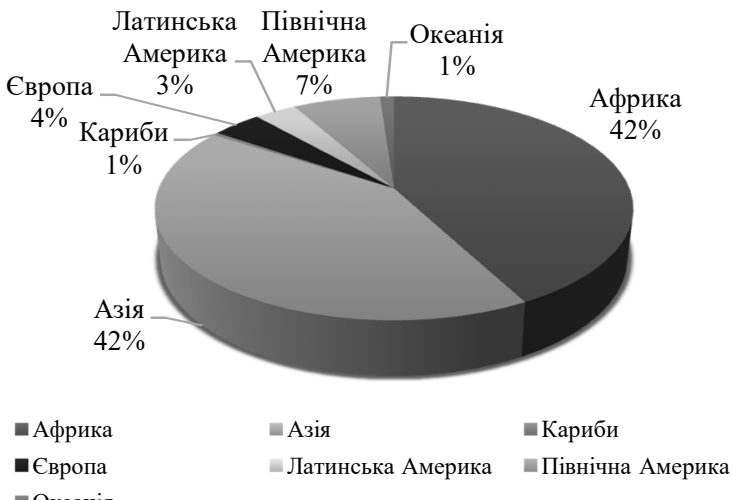

покеанія

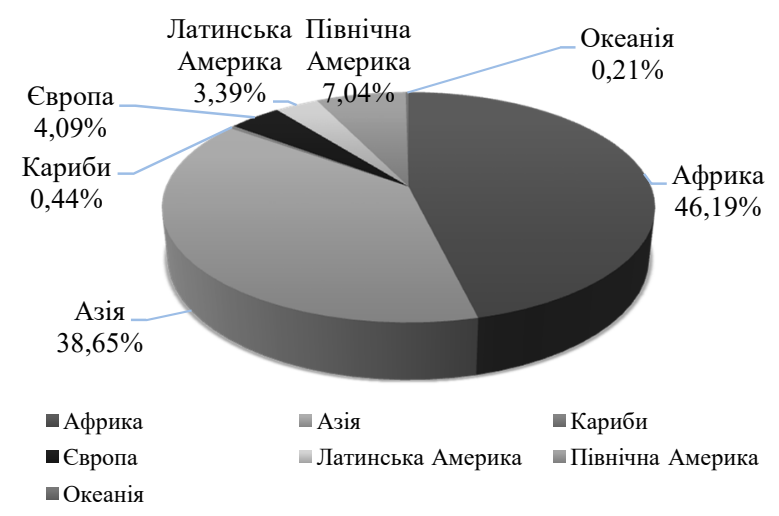

$e$

Рис. 2. Структура кредитних спілок за континентами:

Джерело: [10-15].

a-2013 рік; б-2014 рік; в-2015 рік; г-2016 рік; д-2017 рік; е-2018 рік

Отже, за даними діаграм бачимо, що кредитні спілки поширені по світу досить нерівномірно. Незважаючи на велику кількість кредитних спілок в африканських країнах, найбільші кредитні спілки (за кількістю членів, кредитним портфелем, обсягами залучених коштів та активів) знаходяться в Північній Америці. Щорічно кількість кредитних спілок у цих країнах знижується (за 5 років скорочення становить майже $9 \%$ ), проте на Канаду та США припадає близько $82 \%$ від загального обсягу всіх активів кредитних спілок. Водночас у цих країнах прослідковується один із найвищих показників проникнення - близько 50 \% за весь досліджуваний період. Цей показник розрахо- 
ФІНАНСОВІ РЕСУРСИ: ПРОБЛЕМИ ФОРМУВАННЯ ТА ВИКОРИСТАННЯ

вується шляхом ділення загальної кількості зареєстрованих членів кредитних спілок на економічно активне населення віком 15-64 роки. А зменшення кількості пояснюється звичайною конкуренцією: більші кредитні спілки витісняють із ринку менші.

Також можемо побачити, що структура розташування кредитних спілок за 5 років залишилась майже незмінною. У відносному вираженні дещо збільшилась кількість кредитних спілок Африки (у той час як у Північній Америці зменшилась), структура діяльності кредитних спілок інших регіонів залишилась приблизно на тому ж рівні.

Кредитні спілки країн Свропи довгий час характеризувались одним із найменших показників проникнення, проте на 2018 рік (як порівняти з 2017 роком) темп приросту становив 194,5\% і показник, який багато років тримався на рівні 3,1-3,4\%, сягнув $9,16 \%$. Але того ж року всі інші показники щодо діяльності кредитних спілок незначно скоротились. Це показує, що ринок послуг кредитних спілок у Європі ще й досі перебуває на стадії становлення і не набув значного поширення серед населення. Високі темпи приросту показника проникнення показав і Карибський регіон $-116,9$ \% і досяг найвищого серед усіх регіонів рівня - 65,21 \%. Так само як у країнах Свропи, всі інші показники знизились, і значно швидшими темпами: обсяги залучених ресурсів скоротились на 49,69 \%, а обсяги наданих кредитів - на 51,61 \%.

\section{Аналіз діяльності кредитних спілок в Україні}

Щодо діяльності кредитних спілок в Україні, то відповідно до даних WOCCU, станом на 2018 рік свою діяльність тут здійснюють 358 кредитних спілок із сумарним обсягом активів у розмірі 88,3 млн доларів і показником проникнення 1,55 \%. Хоча в Україні є достатньо велика кількість кредитних спілок (3-є місце за цим показником у країнах Свропи), однак послуги цих організацій не мають значного попиту серед населення. Крім того, кожного року показники їхньої діяльності знижуються. Відповідно до даних Нацкомфінпослуг, наприкінці 2018 року кількість членів кредитних спілок становила 479,0 тис. осіб, що на 85,1 тис. осіб (15,1\%) менше, ніж наприкінці 2017 року. Також відбулися зміни й у структурі членів кредитних спілок. Зокрема, зменшилися частки членів кредитних спілок, які мають чинні кредитні договори, 3 134,3 тис. осіб до 118,2 тис. осіб та членів кредитних спілок, які мають чинні депозитні договори, 3 21,7 тис. осіб до 17,6 тис. осіб [2].

Причиною таких невтішних показників діяльності кредитних спілок в Україні насамперед $є$ низький рівень довіри населення до фінансового сектору країни загалом, що було спричинено політичними та економічними кризовими явищами. До того ж кредитні кошти на сьогодні в Україні є досить дорогими, особливо якщо порівнювати з країнами Північної Америки, де населення живе переважно за рахунок саме кредитних коштів.

Для вирішення цієї ситуації та популяризації діяльності кредитних спілок в Україні спершу має налагодитись політична та економічна ситуація в країні. Крім того, щоб бути конкурентоспроможними на ринку фінансових послуг, кредитним спілкам необхідно пропонувати населенню як нові продукти, так і нові шляхи доступу до них, використовуючи інноваційні технології.

\section{Зростання потенціалу кредитних спілок за допомогою використання новітніх FinTech технологій}

За даними WOCCU, найбільших темпів зростання досягатимуть ті кредитні спілки, що використовуватимуть у своїй діяльності дистанційні канали обслуговування, а саме надаватимуть основні послуги через Інтернет та мобільні канали. Подальше зростання ролі кредитних спілок на ринку фінансових послуг буде зумовлено потребами споживачів щодо зручності та безпроблемної інтеграції в цифрову економіку. 
ФІНАНСОВІ РЕСУРСИ: ПРОБЛЕМИ ФОРМУВАННЯ ТА ВИКОРИСТАННЯ

Найбільшою популярністю серед населення користуються послуги кредитних спілок, якими можна скористатись за допомогою мобільних додатків. Такі додатки є дуже схожими на «мобільний банкінг», проте адаптовані під специфіку діяльності кредитних спілок.

Також кредитні спілки почали впроваджувати у своїй діяльності чат-боти, що допомагають клієнтам отримати швидку консультацію та відповіді на найпоширеніші запитання щодо послуг тієї чи іншої кредитної спілки.

Нині найбільшим недоліком є те, що кредитні спілки звертають недостатньо уваги на розвиток інноваційних фінансових технологій, тому вони менш конкурентоспроможні, ніж банки. Тому кредитні спілки мають зосередити свою увагу на впровадженні новітніх цифрових технологій. Також кредитні спілки повинні мати свій продукт, що відрізнятиметься від продуктів інших суб'єктів ринку фінансових послуг. 3 одного боку, кредити і депозити є настільки традиційними та усталеними, що важко їх трансформувати в щось нове. Водночас кредитні спілки можуть запровадити новий спосіб їх надання та обслуговування.

Тенденції сучасного світу рухаються в бік цифрової економіки та дистанційних каналів надання послуг. Тому, як і інші компанії, кредитні спілки також мають слідкувати за нововведеннями у сфері FinTech трендів і відповідати вимогам клієнтів для того, щоб і надалі провадити свою діяльність.

Українським кредитним спілкам необхідно насамперед знати та розуміти запити своїх клієнтів і відповідати їхнім вимогам. Українські фінансові організації менш стрімко розвивають свої технології, проте саме це і сповільнює їхній розвиток.

Впровадження у свою діяльність мобільних додатків - це один із найперших кроків для масштабування наданих послуг кредитними спілками. Крім того, усі технології, що використовуватимуться, мають бути синхронізовані із сучасними CRM-системами, які матимуть на меті вивчення психології клієнта, визначення його потреб та своєчасне реагування на нові запити.

Важливим фактором розвитку кредитних спілок $є$ також використання «хмарних» технологій. Хмарні рішення є способом:

- скористатися можливостями бізнесу за мить, а не за місяці;

- масштабувати ділові операції за мить;

- позбавити їхню IT-команду від підтримки ще однієї системи;

- отримати вигоду від інших рішень, доступних у тій же екосистемі.

Нині банки та кредитні спілки готові прийняти гібридні хмарні рішення для розробки інтерфейсів клієнтів, ділових правил чи документів, зберігаючи на власних серверах дані клієнтів.

Такі технології дадуть змогу не лише якісно надавати послуги клієнтам, а й, вивчаючи їхні потреби, мати змогу спрогнозувати їхні майбутні запити.

Висновки і пропозиції. Як свідчить проведене дослідження, кредитні спілки відіграють важливу роль на ринку небанківських фінансових послуг. Темпи зростання обсягів діяльності таких організацій дозволяють говорити про потребу населення в альтернативних шляхах отримання кредитних коштів та додаткових можливостях заощадження. Також є тенденція до стрімкого скорочення кількості кредитних спілок у деяких регіонах, хоча масштабність їхньої діяльності розширюється. Це свідчить про нездатність деяких спілок на ринку витримувати конкуренцію на ринку. До того ж зменшується і кількість відділень кредитних спілок, адже в розвинених країнах віддають перевагу дистанційному наданню послуг кредитними спілками.

Аналіз діяльності кредитних спілок також показав, що попит на їхні послуги у світі зростає. Про це свідчать зростання не тільки активів, а й обсягів залучених коштів та наданих кредитів. Не можна залишати без уваги й показник проникнення, адже саме його збільшення говорить про необхідність послуг кредитних спілок для населення. 
ФІНАНСОВІ РЕСУРСИ: ПРОБЛЕМИ ФОРМУВАННЯ ТА ВИКОРИСТАННЯ

Дослідження також продемонструвало, що найближчим часом ринок і надалі зростатиме і на сьогодні немає передумов для його стрімкого падіння. Нині одним із найбільш вагомих явищ, що може негативно вплинути на масштабність діяльності кредитних спілок, є світова криза, що, за пронозами деяких економістів, може виникнути в найближчі 3-5 років.

Варто зазначити, що кредитні спілки можуть легко конкурувати з банками та іншими фінансовими установами на ринку фінансових послуг, особливо, якщо кредитні спілки інвестуватимуть у FinTech технології та зосередять свою увагу на запитах споживачів.

Найбільш дієвим способом для розширення своєї діяльності серед населення $\epsilon$ використання FinTech трендів та дистанційних каналів обслуговування.

В епоху діджиталізації та цифрової економіки на ринку виживатимуть ті компанії, які спрямують свої зусилля на надання послуг у найбільш зручному для клієнта форматі. А враховуючи виклики сучасності, вимогами споживачів $є$ : швидкість доступу до послуг, можливість отримувати послуги дистанційно з будь-якої точки країни / світу, зручність у використанні. Про це свідчать і коментарі представників WOCCU, які наголошують на важливості використання сучасних каналів продажу.

Навчившись приймати та працювати з новими запитами клієнтів, одночасно використовуючи технології та найкращі FinTech практики, кредитні спілки зможуть залишатися актуальними та краще конкурувати 3 великими банками та іншими фінансовими установами та зміцнювати їх відносини.

У процесі дослідження було визначено, що використання FinTech технологій кредитними спілками в Україні є також важливим фактором їхнього розвитку, а особливо в умовах падіння попиту населення на послуги кредитних спілок.

\section{Список використаних джерел}

1. Всеукраїнська асоціація кредитних спілок. Зведені данні кредитних спілок-членів ВАКС станом на 01.07.2019 року. URL: http://vaks.org.ua/images/files/2019/analiz/Analiz_2_kv_2019.pdf.

2. Звіт «Підсумки діяльності кредитних спілок за 2018 рік» Нацкомфінпослуг. URL: https://www.nfp.gov.ua/files/OgliadRinkiv/KS/ks_2018.pdf.

3. Костюк В. А., Шафарчук Л. С. Тенденції розвитку кредитних спілок в Україні. Гроші, фінанси і кредит. 2018. № 25. С. 695-700.

4. Національна асоціація Федеральних кредитних спілок. Economic \& CU Monitor. 2019. URL: http://www.nafcu.org.

5. Осадець О. М., Швець Н. Р. Особливості механізму формування капіталу кредитних спілок України. Scientific journal Innovative solutions in modern science. 2017. № 2 (11). C. 44-58.

6. Осадчий Є. С. Розвиток міжнародної структури кредитної кооперації. Економіка та держава. 2017. № 9. С. 64-69.

7. Про кредитні спілки: Закон України від 20.12.2001 № 2908-III. URL: https://zakon.rada.gov.ua/laws/main/2908-III.

8. Руська Р. Оцінювання позицій кредитних спілок на світовому ринку фінансових послуг. Журнал європейської економіки. 2017. № 2. С. 207-223.

9. Савчук Н. В., Золотарьова О. В. Розвиток кредитних спілок як чинник соціальної та діяльнісної мобільності в українському суспільстві. Науковий вісник Херсонського державного університету. 2019. № 33. С. 204-208.

10. Статистичний звіт Всесвітньої ради кредитних спілок за 2013 рік (WOCCU Statistical Report 2013). URL: https://www.woccu.org/documents/2013_Statistical_Report.

11. Статистичний звіт Всесвітньої ради кредитних спілок за 2014 рік (WOCCU Statistical Report 2014). URL: https://www.woccu.org/documents/2014_Statistical_Report.

12. Статистичний звіт Всесвітньої ради кредитних спілок за 2015 рік (WOCCU Statistical Report 2015). URL: https://www.woccu.org/documents/2015_Statistical_Report_WOCCU.

13. Статистичний звіт Всесвітньої ради кредитних спілок за 2016 рік (WOCCU Statistical Report 2016). URL: https://www.woccu.org/documents/2016_Statistical_Report. 
ФІНАНСОВІ РЕСУРСИ: ПРОБЛЕМИ ФОРМУВАННЯ ТА ВИКОРИСТАННЯ

14. Статистичний звіт Всесвітньої ради кредитних спілок за 2017 рік (WOCCU Statistical Report 2017). URL: https://www.woccu.org/documents/2017 Statistical Report-Revised Nov 2018.

15. Статистичний звіт Всесвітньої ради кредитних спілок за 2018 рік (WOCCU Statistical Report 2018). URL: https://www.woccu.org/documents/2018_Statistical_Report.

16. 2 Big FinTech Goals for Credit Unions (2019). CU Solutions Group. URL: https://www.cusolutionsgroup.com/trends/2-big-fintech-goals-for-credit-unions.

17. Antoine Hemon-Laurens (2019). Thriving During the Fintech Revolution: 4 Power Moves for Traditional Banks and Credit Unions. Quadient. URL: https://www.quadient.com/newsevents/thriving-during-fintech-revolution-4-power-moves-traditional-banks-and-credit-unions.

18. Belekevich T. Promoting credit union digitization in the «world's most advanced digital society». CU Insight. 2019. URL: https://www.cuinsight.com/promoting-credit-union-digitization-inthe-worlds-most-advanced-digital-society.html.

19. Boles T. Credit unions are more popular than ever - are they right for you if you need a loan or want to save? The Sun. 2019. URL: https://www.thesun.co.uk/money/10252585/credit-unionsloans-savings-bank-of-england.

20. Chambers J. Leaning In: Credit Unions And The Fintech Revolution. CU Management. 2019. URL: https://www.cumanagement.com/articles/2019/10/leaning-credit-unions-and-fintech-revolution.

21. Credit Unions: 3 Business-Boosting Trends For 2019. DataTree. 2019. URL: https://www.datatree.com/insights-blog/credit-unions-3-business-boosting-trends-for-2019.

22. Handel B. 2019 Trends in the Credit Union Industry: A Return to More Traditional Growth Strategies. Fiserve Inc. 2019. URL: https://fiserv.com/en/about-fiserv/the-point/2019-trends-in-thecredit-union-industry-a-return-to-more-traditional-growth-strategies.html.

23. Morgan R. The top FinTech trends driving the next decade / American Bankers Association. ABA Banking Journal New York. 2017. Vol. 109 ( $5^{\text {th }}$ ed.). P. 22-27.

24. National Association of Federally-Insured Credit Unions. Regulatory approaches to financial technology. National Association of Federally-Insured Credit Unions. 2019. URL: https://www.nafcu.org/system/files/files/NAFCU-Fintech-White-Paper-Sept2019.pdf.

25. O'Hara T. Credit Union Industry Trends to Follow to Make 2019 the Best Year Yet. Credit Union Business. 2019. URL: https://creditunionbusiness.com/credit-union-industry-trends-to-followto-make-2019-the-best-year-yet.

26. Rod McDermott, Brandon Biegenzahn. Fintech - what you already know and how to address it. McDermott\&Bull. 2019. URL: https://mbexec.com/wp-content/uploads/2017/01/McDermott-BullMarket-Trend-The-Response-to-Fintech.pdf.

27. Special Report: Fintech Credit Union Management. CU Management. 2019. URL: https://www.cumanagement.com/sites/default/files/2018-10/Special_Report_Oct18_vWeb.pdf.

28. Streeter B. Massive Forces Impacting the Future of Bank \& Credit Union Branches. The Financial Brand. 2019. URL: https://thefinancialbrand.com/90421/future-transformation-bank-creditunion-branches-digital-platform.

29. Wingard L. 4 Trends Shaping the Banking \& Credit Union Industry in 2019. Hitachi Solutions. 2019. URL: https://us.hitachi-solutions.com/blog/top-banking-and-credit-union-trends.

\section{References}

1. Vseukrainska asotsiatsiia kredytnykh spilok. Zvedeni danni kredytnykh spilok-chleniv VAKS stanom na 01.07.2019 roku [All-Ukrainian Association of Credit Unions. Summary data of WACS credit unions as of 01.07.2019]. Retrieved from http://vaks.org.ua/images/files/2019/analiz/ Analiz_2_kv_2019.pdf.

2. Zvit «Pidsumky diialnosti kredytnykh spilok za 2018 rik» Natskomfinposluh [Report on the results of credit unions for 2018 of the National Financial Services Commission]. Retrieved from https://www.nfp.gov.ua/files/OgliadRinkiv/KS/ks_2018.pdf.

3. Kostiuk, V. A., Shafarchuk, L. S. (2018). Tendentsii rozvytku kredytnykh spilok v Ukraïni [Trends of credit unions development in Ukraine]. Hroshi, finansy i kredyt-Money, finance and credit, 25, 695-700 [in Ukrainian].

4. Natsionalna asotsiatsiia Federalnykh kredytnykh spilok [National Association of Federal Credit Unions] (2019). Economic \& CU Monitor. Retrieved from http://www.nafcu.org. 
ФІНАНСОВІ РЕСУРСИ: ПРОБЛЕМИ ФОРМУВАННЯ ТА ВИКОРИСТАННЯ

5. Osadets, O. M., Shvets, N. R. (2017). Osoblyvosti mekhanizmu formuvannia kapitalu kredytnykh spilok Ukrainy [Features of the mechanism of capital formation of credit unions of Ukraine]. Scientific journal Innovative solutions in modern science, 2 (11), 44-58 [in Ukrainian].

6. Osadchyi, Ye. S. (2017). Rozvytok mizhnarodnoi struktury kredytnoi kooperatsii [Development of the international structure of credit cooperation]. Ekonomika ta derzhava - Economy and the state, 9, 64-69 [in Ukrainian].

7. Pro kredytni spilky [On Credit Unions]. № 2908-III (20.12.2001). Retrieved from https://zakon.rada.gov.ua/laws/main/2908-III.

8. Ruska, R. (2017). Otsiniuvannia pozytsii kredytnykh spilok na svitovomu rynku finansovykh posluh [Assessing the position of credit unions in the global financial services market]. Zhurnal yevropeiskoi ekonomiky - Journal of the European Economy, 2, 207-223 [in Ukrainian].

9. Savchuk, N. V., Zolotarova, O. V. (2019). Rozvytok kredytnykh spilok yak chynnyk sotsialnoi ta diialnisnoi mobilnosti v ukrainskomu suspilstvi [Development of credit unions as a factor of social and activity mobility in Ukrainian society]. Naukovyi visnyk Khersonskoho derzhavnoho universytetu - Scientific Bulletin of Kherson State University, 33, 204-208 [in Ukrainian].

10. Statystychnyi zvit Vsesvitnoi rady kredytnykh spilok za 2013 rik (WOCCU Statistical Report 2013). Retrieved from https://www.woccu.org/documents/2013_Statistical_Report.

11. Statystychnyi zvit Vsesvitnoi rady kredytnykh spilok za 2014 rik (WOCCU Statistical Report 2014). Retrieved from https://www.woccu.org/documents/2014_Statistical_Report.

12. Statystychnyi zvit Vsesvitnoi rady kredytnykh spilok za 2015 rik (WOCCU Statistical Report 2015). Retrieved from https://www.woccu.org/documents/2015_Statistical_Report_WOCCU.

13. Statystychnyi zvit Vsesvitnoi rady kredytnykh spilok za 2016 rik (WOCCU Statistical Report 2016). Retrieved from https://www.woccu.org/documents/2016_Statistical_Report.

14. Statystychnyi zvit Vsesvitnoi rady kredytnykh spilok za $201 \overline{7}$ rik (WOCCU Statistical Report 2017). Retrieved from https://www.woccu.org/documents/2017_Statistical_ReportRevised_Nov_2018.

15. Statystychnyi zvit Vsesvitnoi rady kredytnykh spilok za 2018 rik (WOCCU Statistical Report 2018). Retrieved from https://www.woccu.org/documents/2018_Statistical_Report.

16. 2 Big FinTech Goals for Credit Unions (2019). CU Solutions Group. Retrieved from https://www.cusolutionsgroup.com/trends/2-big-fintech-goals-for-credit-unions.

17. Antoine Hemon-Laurens (2019). Thriving During the Fintech Revolution: 4 Power Moves for Traditional Banks and Credit Unions. Quadient. Retrieved from https://www.quadient.com/newsevents/thriving-during-fintech-revolution-4-power-moves-traditional-banks-and-credit-unions.

18. Belekevich, T. (2019). Promoting credit union digitization in the «world's most advanced digital society». $C U$ Insight. Retrieved from https://www.cuinsight.com/promoting-credit-uniondigitization-in-the-worlds-most-advanced-digital-society.html.

19. Boles, T. (2019). Credit unions are more popular than ever - are they right for you if you need a loan or want to save? The Sun. Retrieved from URL: https://www.thesun.co.uk/money/ 10252585/credit-unions-loans-savings-bank-of-england.

20. Chambers, J. (2019). Leaning In: Credit Unions And The Fintech Revolution. $C U$ Management. Retrieved from https://www.cumanagement.com/articles/2019/10/leaning-credit-unionsand-fintech-revolution.

21. Credit Unions: 3 Business-Boosting Trends For 2019. DataTree (2019). Retrieved from https://www.datatree.com/insights-blog/credit-unions-3-business-boosting-trends-for-2019.

22. Handel, B. (2019). 2019 Trends in the Credit Union Industry: A Return to More Traditional Growth Strategies. Fiserve Inc. Retrieved from https://fiserv.com/en/about-fiserv/the-point/2019trends-in-the-credit-union-industry-a-return-to-more-traditional-growth-strategies.html.

23. Morgan, R. (2017). The top FinTech trends driving the next decade / American Bankers Association. ABA Banking Journal New York, 109 ( $5^{\text {th }}$ ed.), 22-27.

24. National Association of Federally-Insured Credit Unions. Regulatory approaches to financial technology (2019). National Association of Federally-Insured Credit Unions. URL: https://www.nafcu.org/system/files/files/NAFCU-Fintech-White-Paper-Sept2019.pdf. 
ФІНАНСОВІ РЕСУРСИ: ПРОБЛЕМИ ФОРМУВАННЯ ТА ВИКОРИСТАННЯ

25. O'Hara, T. (2019). Credit Union Industry Trends to Follow to Make 2019 the Best Year Yet. Credit Union Business. Retrieved from https://creditunionbusiness.com/credit-union-industry-trendsto-follow-to-make-2019-the-best-year-yet.

26. Rod McDermott, Brandon Biegenzahn (2019). Fintech - what you already know and how to address it. McDermott\&Bull. Retrieved from https://mbexec.com/wp-content/uploads/2017/01/ McDermott-Bull-Market-Trend-The-Response-to-Fintech.pdf.

27. Special Report: Fintech Credit Union Management (2019). CU Management. Retrieved from https://www.cumanagement.com/sites/default/files/2018-10/Special_Report_Oct18_vWeb.pdf.

28. Streeter, B. (2019). Massive Forces Impacting the Future of Bank \& Credit Union Branches. The Financial Brand. Retrieved from https://thefinancialbrand.com/90421/future-transformationbank-credit-union-branches-digital-platform.

29. Wingard, L. (2019). 4 Trends Shaping the Banking \& Credit Union Industry in 2019. Hitachi Solutions. 2019. Retrieved from https://us.hitachi-solutions.com/blog/top-banking-and-creditunion-trends.

Поліщук Євгенія Анатоліївна - доктор економічних наук, професор, професор кафедри корпоративних фінансів і контролінгу, ДВНЗ «Київський національний економічний університет імені Вадима Гетьмана» (просп. Перемоги, 54/1, м. Київ, 03157, Україна).

Полищук Евгения Анатольевна - доктор экономических наук, профессор, профессор кафедры корпоративных финансов и контроллинга, ГВУЗ «Киевский национальный экономический университет имени Вадима Гетьмана» (просп. Победы, 54/1, г. Киев, 03157, Украина).

Polishchuk Yevheniia - Doctor of Economics, Professor, Professor of Corporate Finance and Controlling Department, SHEE «Kyiv National Economic University named after Vadym Hetman» (54/1 Peremogy Av., 03157 Kyiv, Ukraine).

E-mail: polishchuk@kneu.edu.ua

ORCID: http://orcid.org/0000-0002-6133-910X

ResearcherID: https://publons.com/a/1525280

Орел Вікторія Сергіївна - спеціаліст Управління кредитної експертизи, АТ «ТАСКОМБАНК» (вул. Симона Петлюри, 30, м. Київ, 01032, Україна).

Орел Виктория Сергеевна - специалист Управления кредитной экспертизы, АО «ТАСКОМБАНК» (ул. Симона Петлюры, 30, г. Киев, 01032, Украина).

Orel Viktoriia - Specialist of credit analysis unit, JSC «TASCOMBANK» (30 Symona Petliury Str., 01032 Kyiv, Ukraine).

E-mail: orelvs@ukr.net 